Figure 38. Francisco de Zurbarán, Miraculous Mass of Fray Pedro de Cabañuelas.

Figure 39. Francisco de Zurbarán, Bishop Gonzalo de Illescas.

Figure 40. Francisco de Zurbarán, Temptation of Fray Diego de Orgaz.

Figure 41. Francisco de Zurbarán, Vision of Fray Pedro de Salamanca.

Figure 42. Composite view of present arrangement of paintings in the sacristy, Guadalupe.

Figure 43. Composite view of proposed re-arrangement of paintings in the sacristy, Guadalupe.

Figure 44. Juan de Valdés Leal, In Ictu Oculi.

Figure 45. Juan de Valdés Leal, Finis Gloriae Mundi.

Figure 46. Bartolomé Murillo, Moses Sweetening the Waters of Mara.

Figure 47. Bartolomé Murillo, Feeding of the Five Thousand.

Figure 48. Bartolomé Murillo, Return of the Prodigal Son.

Figure 49. Bartolomé Murillo, Christ Healing the Paralytic.

Figure 50. Bartolomé Murillo, Liberation of St. Peter.

Figure 51. Bartolomé Murillo, Abraham and the Three Angels.

Figure 52. Bartolomé Murillo, St. Elizabeth of Hungary Healing the Sick.

Figure 53. Bartolomé Murillo, Charity of St. John of God.

Figure 54. Bernardo Simon de Pineda, Pedro Roldán, Juan de Valdés Leal and Bartolomé Murillo, altarpiece, Caridad.

Figure 55. Pedro Roldán and Bartolomé Murillo, Entombment of Christ.

\title{
PHOTOGRAPH CREDITS
}

Archivo Histórico Nacional,

Madrid-29, 31

Art Institute, Chicago-11

Biblioteca Nacional, Madrid-30

Biblioteca Vaticana, Vatican-25

Sandra Brown-26

Philip Evola-33, 42, 43

Hermitage, Leningrad-50

Instituto de Conservación y Restauración, Madrid-16-22

Laboratorio de Arte, University of Seville-2, 3
Mas-1, 5-6, 8, 10, 12-13, 15, 27, 28, $32,34-41,44-47,52-55$

Musée de Grenoble, Grenoble-4

Museo del Prado, Madrid-7, 9, 14, 23-24

National Gallery, London-49

National Gallery of Art, Washington -48

National Gallery of Canada,

Ottawa-51 



\section{Images and Ideas}

in Seventeenth-Century

Spanish Painting 
